\title{
Blepharitis: a rare side effect related to cetuximab in patient with colorectal cancer
}

\author{
Sukesh Manthri, Kanishka Chakraborty
}

Division of Hematology/ Oncology, Department of Internal Medicine, East Tennessee State University, Johnson City, Tennessee, USA

\section{Correspondence to} Dr Kanishka Chakraborty, chakrabk@etsu.edu

Accepted 21 August 2019

\section{DESCRIPTION}

Molecular targeted agents have emerged as an important part of systemic therapy for many cancer types. Cetuximab is a recombinant human/ mouse chimeric monoclonal antibody which competitively inhibits the binding of epidermal growth factor (EGF) and other ligands were approved for metastatic colon cancer in $2004 .^{1}$ Skin toxicity is the most important side effect of cetuximab administration, but blepharitis as ocular toxicity was reported in $<1 \%$, postmarketing and/or case reports. ${ }^{2-5}$ A 61 -year-old woman due to lack of proper health surveillance presented with complaints of abdominal pain and bloody stools. CT scan showed $4.2 \times 3$ $\mathrm{cm}$ mass at the gastric antrum/pylorus, $2.8 \times 1.7$ $\mathrm{cm}$ polypoid mass near the transverse colon. It also showed multiple large hypodense lesions in the liver. Subsequently, a liver biopsy confirmed metastatic adenocarcinoma favoured to represent colonic primary based on immunostains (positive for CDX2, CK 20 and negative for SATB2). There was no evidence of mismatch repair deficiency. KRAS and BRAF mutation was not detected. Status post 10 cycles of FOLFIRI (5-fluorouracil, leucovorin and irinotecan) plus cetuximab treatment patient developed inflammation of the eyelid margin associated with eye irritation (figures 1 and 2). Cetuximab was held, and she was treated with topical antibiotics and her clinical signs and symptoms of blepharitis have resolved. The two classes of molecular targeted agents associated with blepharitis are the EGF receptor inhibitors and the proteasome inhibitor (like bortezomib). Severe blepharitis has been implicated as an adverse event of bortezomib and is often refractory to conservative treatment requiring oral antimicrobials like doxycycline. ${ }^{6}$ A cetuximab-related ocular side effect is rare, and the pathogenesis is not clearly established. Meibomian glands are the sebaceous glands of the eye that secrete tears, similar to the sweat gland apparatus of the

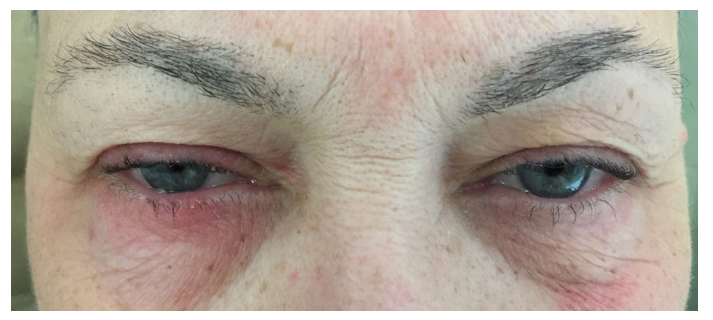

Figure 1 Picture depicting inflammation of the eyelid margin associated with eye irritation.

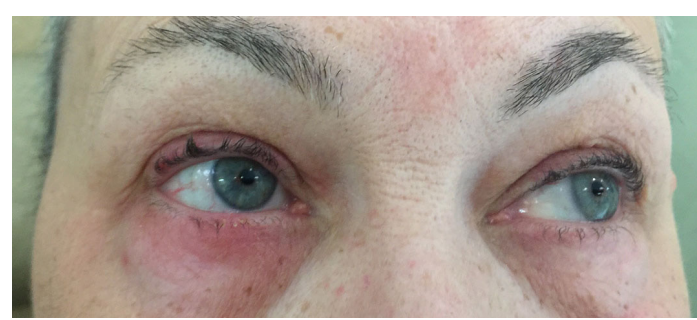

Figure 2 With raised eyebrows, picture depicting inflammation of the eyelid margin associated with eye irritation more clearly.

\section{Learning points}

- Blepharitis is a rare but known side effect of cetuximab.

- The two classes of molecular targeted agents associated with blepharitis are the epidermal growth factor receptor inhibitors and the proteasome inhibitor.

- The mild cases of eye toxicity may be controlled with conservative approach, but severe cases will require collaboration with ophthalmologist.

skin. Previous case reports have hypothesised that cetuximab targets the EGFR-expressing cells of meibomian glands and may consequently lead to altered secretive function. ${ }^{7}$ The mild cases of eye toxicity may be controlled with the conservative approach, but severe cases will require collaboration with an ophthalmologist. ${ }^{8}$ Epithelial defects are reversible with cessation of treatment and the decision to continue therapy must be individualised taking into account the risks and the availability of alternative treatments. ${ }^{9}$ Treating physicians should maintain a high degree of caution and monitor for such rare toxicities in patients on EGFR inhibitors.

Contributors SM worked on the abstract and reviewed the literature. KC supervised, guided and edited the abstract.

Funding The authors have not declared a specific grant for this research from any funding agency in the public, commercial or not-for-profit sectors.

Competing interests None declared.

Patient consent for publication Obtained.

Provenance and peer review Not commissioned; externally peer reviewed. 
Images in...

\section{REFERENCES}

1 FDA. Information on cetuximab (marketed as Erbitux). https://www.fda.gov/drugs/ postmarket-drug-safety-information-patients-and-providers/information-cetuximabmarketed-erbitux

2 Dranko S, Kinney C, Ramanathan RK. Ocular toxicity related to cetuximab monotherapy in patients with colorectal cancer. Clin Colorectal Cancer 2006:6:224-5.

3 Melichar B, Nemcová I. Eye complications of cetuximab therapy. Eur J Cancer Care 2007:16:439-43.

4 Ramírez-Soria MP, España-Gregori E, Aviñó-Martínez J, et al. [Blepharitis related to cetuximab treatment in an advanced colorectal cancer patient]. Arch Soc Esp Oftalmol 2008;83:665-8.
5 Criado PR, Lima AA. Blepharitis and trichomegaly induced by cetuximab. An Bras Dermatol 2010:85:919-20.

6 Veys MC, Delforge M, Mombaerts I. Treatment with doxycycline for severe bortezomibassociated blepharitis. Clin Lymphoma Myeloma Leuk 2016;16:e109-e112.

7 Tonini G, Vincenzi B, Santini D, et al. Ocular toxicity related to cetuximab monotherapy in an advanced colorectal cancer patient. J Natl Cancer Inst 2005;97:606-7.

8 Lindsley K, Matsumura S, Hatef E, et al. Interventions for chronic blepharitis. Cochrane Database Syst Rev 2012;5:CD005556.

9 Johnson KS, Levin F, Chu DS. Persistent corneal epithelial defect associated with erlotinib treatment. Cornea 2009;28:706-7.

Copyright 2019 BMJ Publishing Group. All rights reserved. For permission to reuse any of this content visit https://www.bmj.com/company/products-services/rights-and-licensing/permissions/

BMJ Case Report Fellows may re-use this article for personal use and teaching without any further permission.

Become a Fellow of BMJ Case Reports today and you can:

Submit as many cases as you like

Enjoy fast sympathetic peer review and rapid publication of accepted articles

- Access all the published articles

Re-use any of the published material for personal use and teaching without further permission

\section{Customer Service}

If you have any further queries about your subscription, please contact our customer services team on +44 (0) 2071111105 or via email at support@bmj.com.

Visit casereports.bmj.com for more articles like this and to become a Fellow 